\title{
Zone Landslide Analysis Using Geophysical Method and Analysis of Soil Type for Disaster Mitigation In Waru Pamekasan
}

\author{
Sandy Vikki Ariyanto*, and Idon Joni \\ Department of Informatics Engineering, Faculty of Engineering, University of Madura, East Java, Jl Raya \\ Panglegur Km. 3,5 Pamekasan 69317, Madura, East Java, Indonesia \\ *sandy@unira.ac.id
}

\section{ABSTRACT}

The results of this study are the factors of landslides there are many cracks in the ground, normal faults, shear faults and slope of the soil surface. The higher the slope of the land surface, the more potential for landslides. Results of XRF Waru $1 \mathrm{Si} 58.3 \%$, Waru $2 \mathrm{Ca} 71.37 \%$, Waru $3 \mathrm{Si} 43.3 \%$. The results of XRD Waru 1 and Waru 2 were $88 \% \mathrm{SiO} 2$ compound, Waru 3 in the form of $\mathrm{CaCo} 3$ compound was $75.2 \%$. SEM results with 10,000x enlargement Waru 1 is almost homogeneous in the form of slabs which identifies an uneven grain size and with a little porosity indicating the sample is partially amorphous in structure, Waru 2 shows an inhomogeneous sample with a fairly high porous dispersion and is not equally, Waru 3 shows the existence of an almost cube crystal form with high porosity so that it causes frequent landslides due to the density of a sand is still lacking so that it makes it easy for the land to be evicted because there are still many cavities in the soil.

Keywords: Landslide, Resistivity, XRF, XRD, SEM

\section{INTRODUCTION}

From the map of natural disaster-prone by the Pamekasan district government it is very clear that the Waru district in purple with the assumption is a critical / disaster-prone area, this map was formed due to a landslide event ${ }^{[1]}$, but the map is still not detailed, therefore researchers choose this location to examine what causes natural hazard-prone zones using geoelectricity and soil testing (Figure 1). This research needs to look in detail which points have the potential for landslides.

Heavy rains that flushed Pamekasan Regency in the past two days caused a cliff in the hills of Sana Laok Village to slide. The location of the incident in Matabe Hamlet, Sana Laok Village, Waru District, about 50 kilometers to the north of Pamekasan City. The landslide cliff was 7 meters long with a height of 8 meters. As a result, the connecting road between villages was cut off. This heavy rain also cut off the 2.5 meters bridge in the village. During the last two days, heavy rains flushed Pamekasan City with moderate to heavy intensity as a result of the cliffs landslides. This state of Waru district is said to be prone to landslides when it rains.

From the results of the study the presence of an active fault in the Pamekasan Regency ${ }^{[2]}$. however, the landslide zone has not yet been determined, so information is incomplete. Therefore, the researchers examined the landslide zone because it has a potential for landslide-prone, using geoelectric methods can look for a landslide-prone zone, and use soil testing to determine the type of soil in the Waru sub-district of Pamekasan district. 
The use of resistivity geoelectric methods can provide information about subsurface layers related to the slip plane ${ }^{[3]}$. ERT functions to look for landslide structures and thickness ${ }^{[4]}$. To determine landslides using Electric Resistivity Tomography (ERT) ${ }^{[5]}$.

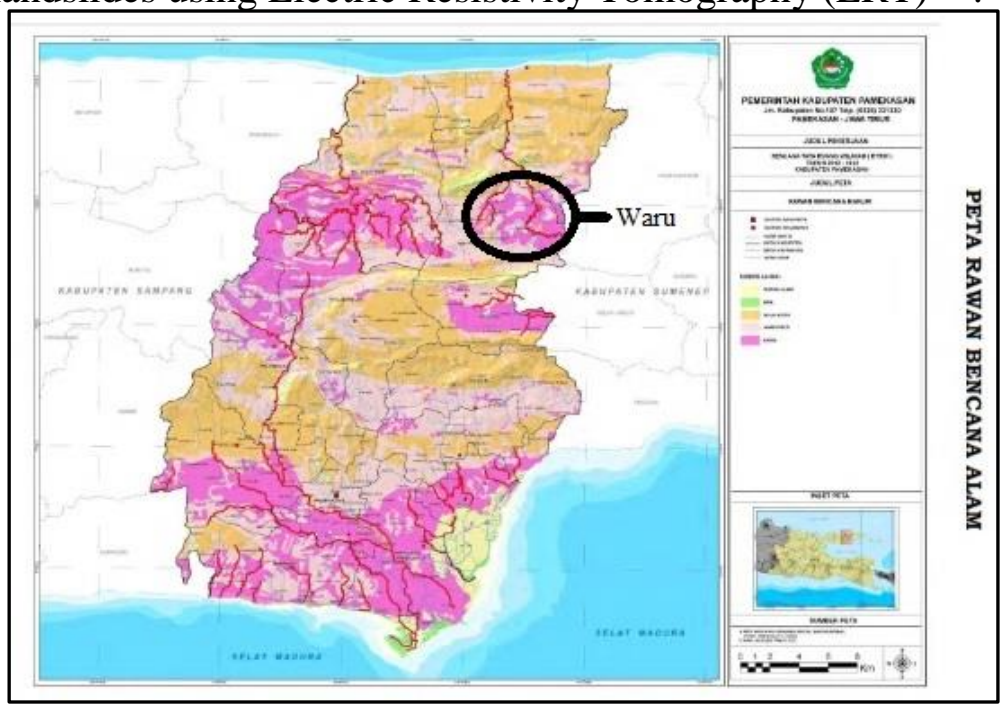

Figure 1. Pamekasan disaster Landslide Map

\section{METHOD}

The geoelectric survey conducted in Waru Kab. Pamekasan, Madura, East Java. This research was conducted in April to September 2019 with a combination of 2 scholarships that is Material Physics and Geophysics.

Geoelectric data collection in this study using 64 Chennel in one slese cycle. It is intended that the correction per data capture point can describe the maximum depth and the points are set with a distance of 10 meters.

After indications of faults and cracks have been found, then soil sampling is done. Three soil samples were taken at faults and cracks were 2 meters deep, 4 meters deep and 6 meters above ground level. after that it was tested using XRD, XRF, and SEM. XRF testing aims to determine the structure based on the material obtained, while XRD aims to determine the structure of the material based on the crystallization structure obtained from other researchers, SEM aims to see the size of the structure and shape of crystallization that is formed completely or not. based on other reference results.

\section{RESULT AND DISCUSSION}

2D cross-section results show that the surface rock resistivity on line $154.1 \Omega \mathrm{m}-272 \Omega \mathrm{m}$, line 234.4 - $309 \Omega \mathrm{m}$, Line 336.5 - $509 \Omega \mathrm{m}$, Line 421.2 - $483 \Omega \mathrm{m}$, Line 539.9 - $800 \Omega \mathrm{m}$ (Figure 2).

Based on the 2D cross section obtained at the top of the location of the cracks identified as layers of quarsa crossing rocks, arbitoid limestone, claystone, and sandstone marred crossing stones, clay gambling stones, sandstone limestone. quartz crosses and limestone as bedrock. quartz and limestone layers were bedrock rocks that were in depths of more than $10 \mathrm{~m}^{[6]}$. slip field with the type of sand in the form of hard clay (bedrock) ${ }^{[7]}$. The occurrence of landslides is a type of clay or clay rock and sandstone ${ }^{[8]}$. surface rock density is one of the factors causing landslides ${ }^{[9]}$. Cracks resistivity values vary between $25 \Omega \mathrm{m}-94 \Omega \mathrm{m}$ with a layer thickness varying from 2.1 meters to 38.4 meters. Line 1 has 4 cracks located at 110 
meters-190 meters, Line 2 has 3 cracks located at 30 meters 120 meters, Line 3 has 4 cracks at 30 meters-160 meters, Line 4 has as many cracks 4 is located on a stretch of 30 meters150 meters, Line 5 there are as many as 6 cracks located on a stretch of 30 meters- 210 meters. Water will accumulate on these cracks due to high rainfall. If that happens it will be very dangerous because gravity will be heavier under the surface which at any time can trigger landslides.

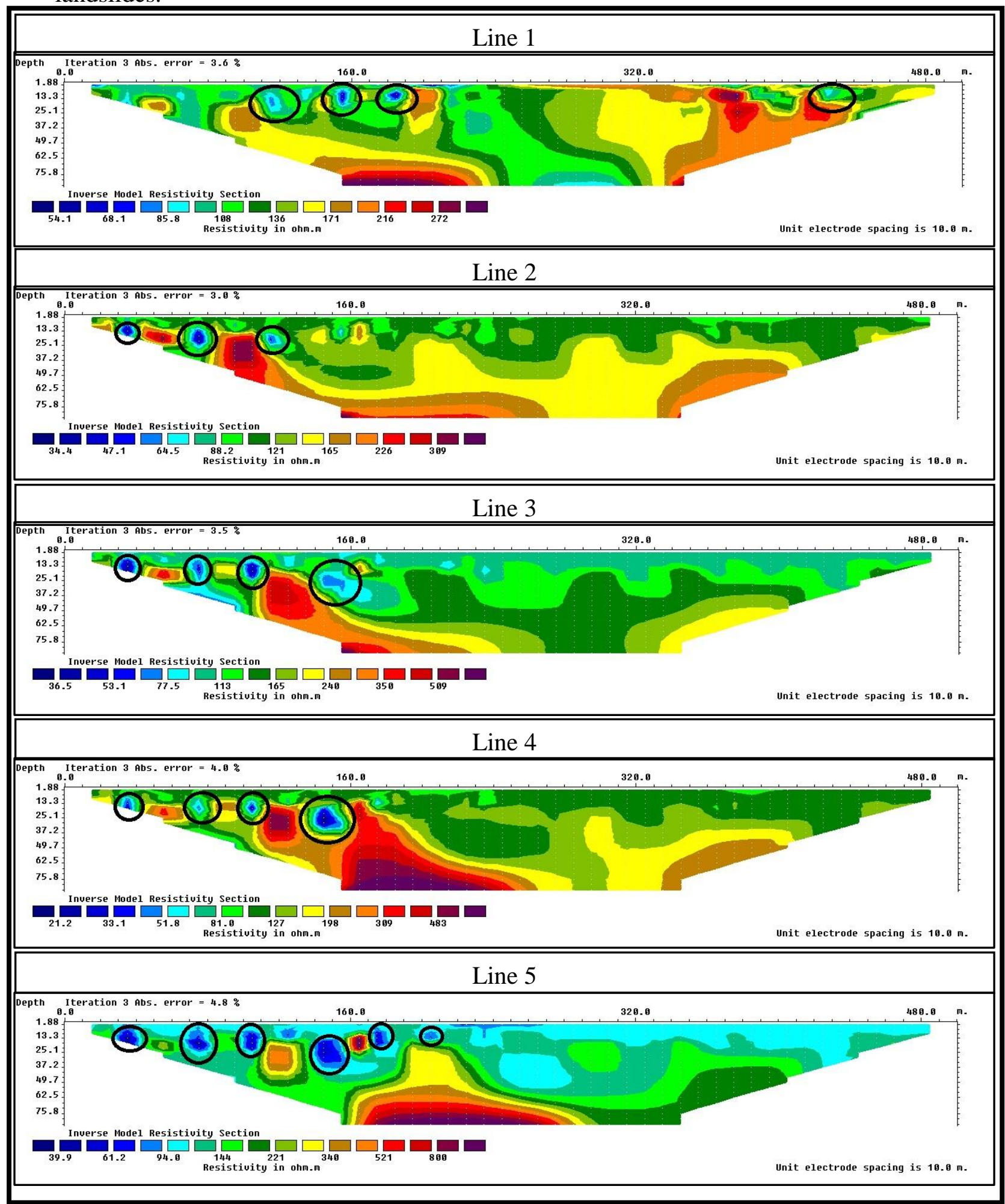

Figure 2. Resistivity Results for Finding Cracks 
Based on the 2D cross-section there are normal faults and sliding faults. This fault is as the slip plane and block movement. Line 6 has a normal fault with a resistivity value of $142 \Omega \mathrm{m}$ at a stretch of 120 meters-410 meters, Line 7 has a sliding fault with a resistivity value of $296 \Omega \mathrm{m}$ at a stretch of 40 meters-370 meters, Line 8 has a normal fault with a resistivity value of $215 \Omega \mathrm{m}$ at a stretch of 100 meters -400 meters (Figure 3 ).

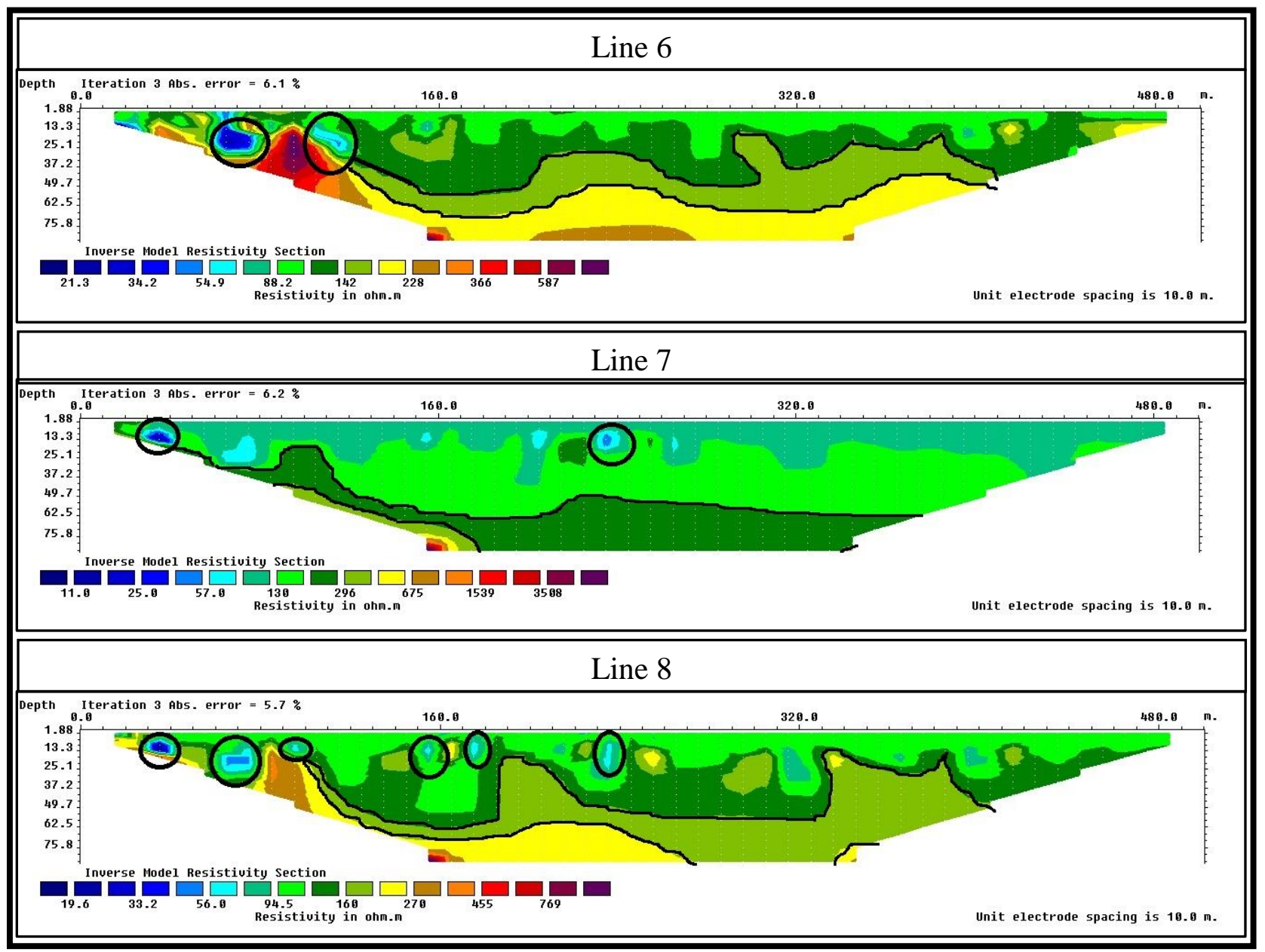

Figure 3. Resistivity Results for Finding Normal Fault and Sliding Fault

Based on the slope of the surface varies in each line (Figure 4). For line 1 surface slope $18^{0}$, line 2 surface slope $20^{\circ}$, line 3 surface slope $17^{\circ}$, line 4 surface slope $21^{0}$, line 5 surface slope $20^{0}$, line 6 surface slope $13^{0}$, line 7 surface slope $15^{0}$, line 8 surface slope $12^{0}$. Meaning line 4 has the potential for a land shift, but it does not rule out the possibility that other lines have the potential for a land shift. Due to cracks, normal faults and sliding faults are on all lines. Supported by research results episodic tilt movements consisting of debris flow, rotational slides, soil material, and shallow translations ${ }^{[10]}$. The slope value causes the instability of subsurface soils that cause landslides. The slope causes the ground to move, causing landslides ${ }^{[11]}$. 


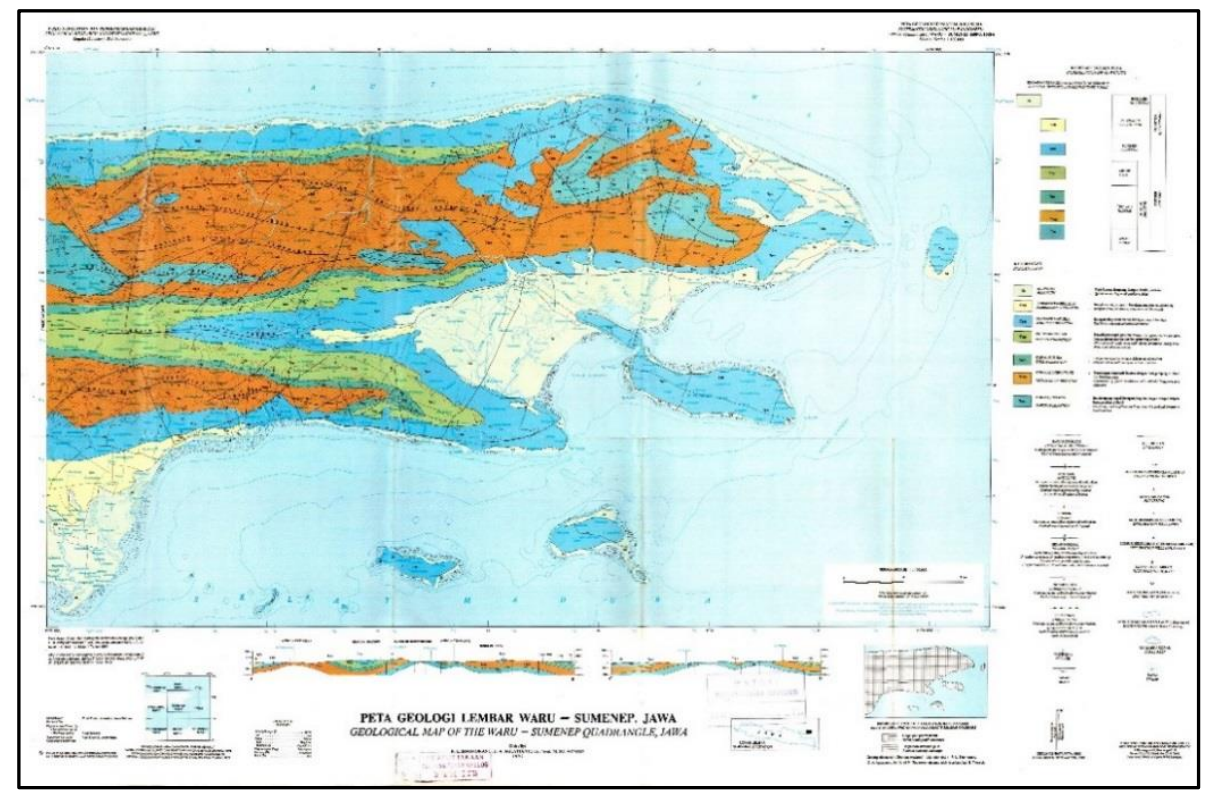

Figure 4. Geological Map Of The Waru

Analysis of samples using X-Ray Fluorescence (XRF) and X-Ray Difraction (XRD). XRF testing is widely used in rock or mineral analysis which aims to look at the elemental content contained in a material. The results of the three ingredients that have been tested are presented XRF (Table 1). waru 1 is a sample that is at a depth of 2 meters, waru 2 is a sample that is at a depth of 4 meters, waru 3 is a sample that is at a depth of 6 meters.

Table 1. XRF Test Results from Waru 1, Waru 2 and Waru 3

\begin{tabular}{cccc}
\hline ELEMENT & WARU 1 (\%) & WARU 2 $(\%)$ & WARU 3 $(\%)$ \\
\hline $\mathrm{Al}$ & 11 & 4,1 & 9,00 \\
$\mathrm{Si}$ & 58,3 & 11,3 & 43,3 \\
$\mathrm{~K}$ & 3,22 & 0,32 & 2,29 \\
$\mathrm{Ca}$ & 5,26 & 71,37 & 15,6 \\
$\mathrm{Ti}$ & 2,05 & 0,83 & 1,92 \\
$\mathrm{~V}$ & 0,084 & 0,05 & 0,10 \\
$\mathrm{Cr}$ & 0,087 & 0,058 & 0,11 \\
$\mathrm{Mn}$ & 0,15 & 0,16 & 0,32 \\
$\mathrm{Fe}$ & 19,4 & 7,60 & 26,2 \\
$\mathrm{Ni}$ & 0,02 & 0,00 & 0,00 \\
$\mathrm{Cu}$ & 0,10 & 0,055 & 0,11 \\
$\mathrm{Sr}$ & 0,00 & 0,72 & 0,00 \\
$\mathrm{Mo}$ & 0,00 & 0,57 & 0,00 \\
$\mathrm{In}$ & 0,00 & 2,4 & 0,00 \\
$\mathrm{Ba}$ & 0,00 & 0,10 & 0,00 \\
$\mathrm{Yb}$ & 0,10 & 0,34 & 0,00 \\
$\mathrm{Re}$ & 0,00 & 0,00 & 0,26 \\
$\mathrm{Eu}$ & 0,20 & 0,07 & 0,30 \\
$\mathrm{~Pb}$ & 0,00 & 0,00 & 0,48 \\
\hline
\end{tabular}

Based on Table 1 shows that the highest chemical element content Waru 1 is Si then followed by $\mathrm{Fe}$ and $\mathrm{Al}$, Waru 2 the highest element content is far different where $\mathrm{Ca}$ in the first sequence is followed by $\mathrm{Si}$ and $\mathrm{Fe}$, Waru 3 the highest element content is far different where $\mathrm{Si}$ in The first sequence is followed by $\mathrm{Fe}$ and $\mathrm{Ca}$. the highest peak percentage of the three samples in a row that is Si 58.3\% (Waru 1), Ca 71.37\% (Waru 2), Si 43.3\% (Waru 3). In the 
test results of this element content, for Waru 1 and Waru 3 is almost the same which is the highest aggregate, $\mathrm{Si}$. while the highest aggregate Waru 2 is $\mathrm{Ca}$.

In testing 3 samples with long angles $\left(10^{\circ}-90^{\circ}\right)$. This is done because 3 samples are natural minerals. Based on the results of the XRD test showed the crystallinity of the sample (Figure 5). crystal diffraction peaks have formed with small and high peaks but there are still sloping peaks which are indicated as amorphous.

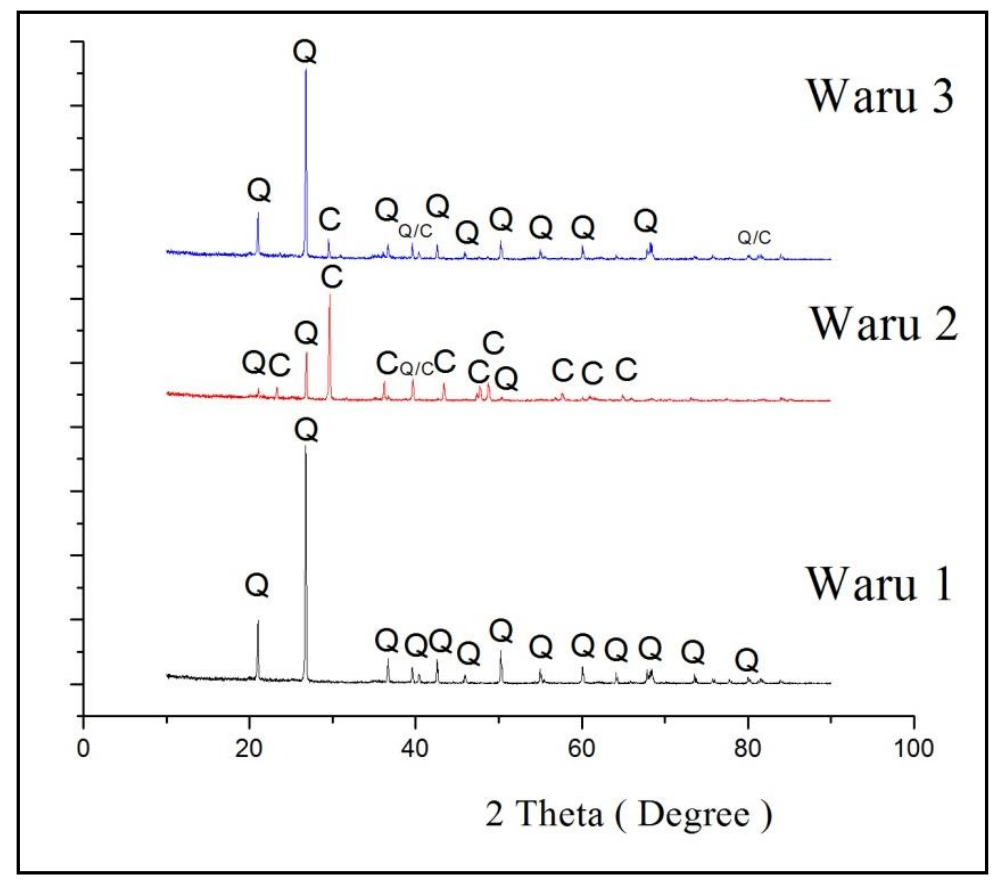

Figure 5. XRD testing of Waru 1, Waru 2 and Waru 3

Based on Figure 5 above shows that in the Waru 1 sample the element content is $\mathrm{Si}(>90 \%)$ by ignoring the peak ramps identified by the amorphous phase. In the Waru 2 sample, the content of the elements was $75.2 \% \mathrm{CaCo} 3$ and $24.8 \% \mathrm{SiO} 2$, while the Waru 3 had $89.3 \%$ $\mathrm{SiO} 2$ content and $10.7 \% \mathrm{CaCo} 3$.

The three samples have a match of $100 \%$ for the highest elemental content. However, the three samples have in common the Fe is lost at the time of analysis using the Match Software where $\mathrm{Fe}$ is the second aggregate of the highest percentage of the XRF results. That is due to several possibilities, the first is the possibility of forming Pigeonite material caused by Fe atoms that bind to other atoms, the second is the possibility of Fe Forming Crystals with the same structure as $\mathrm{CaCO} 3$ and $\mathrm{SiO} 2$ by forming symmetry of scalenohedral hexagonal trigonal crystals $32 / \mathrm{m}$. The third $\mathrm{Fe}$ forms amorphous phases such as $\mathrm{FeO}(\mathrm{OH})$ (Goethite) ${ }^{[12]}$. it was also evidenced by the results of SEM with the presence of clusters in the form of slabs and high porosity ${ }^{[13]}$.

In Testing 3 samples with 10,000X Magnification. This test aims to look at the morphology and crystallization phase in the sample. SEM results show that (a) a nearly homogeneous sample in the form of a slab that identifies an uneven grain size and with a little porosity indicates the sample is partially amorphous in structure, It is also supported by the XRD results using the help of Software Match that formed 1 phase namely $\mathrm{SiO} 2(>90 \%)$. (b) the sample is not homogeneous (the distribution of $\mathrm{CaCO} 3$ and $\mathrm{SiO} 2$ is uneven) with a fairly high and uneven distribution of porosity. (c) the sample shows the existence of an almost 
cube crystal shape with a homogeneity higher than Waru 2, but the porosity is higher than Waru 1 and Waru 2 (Figure 6).

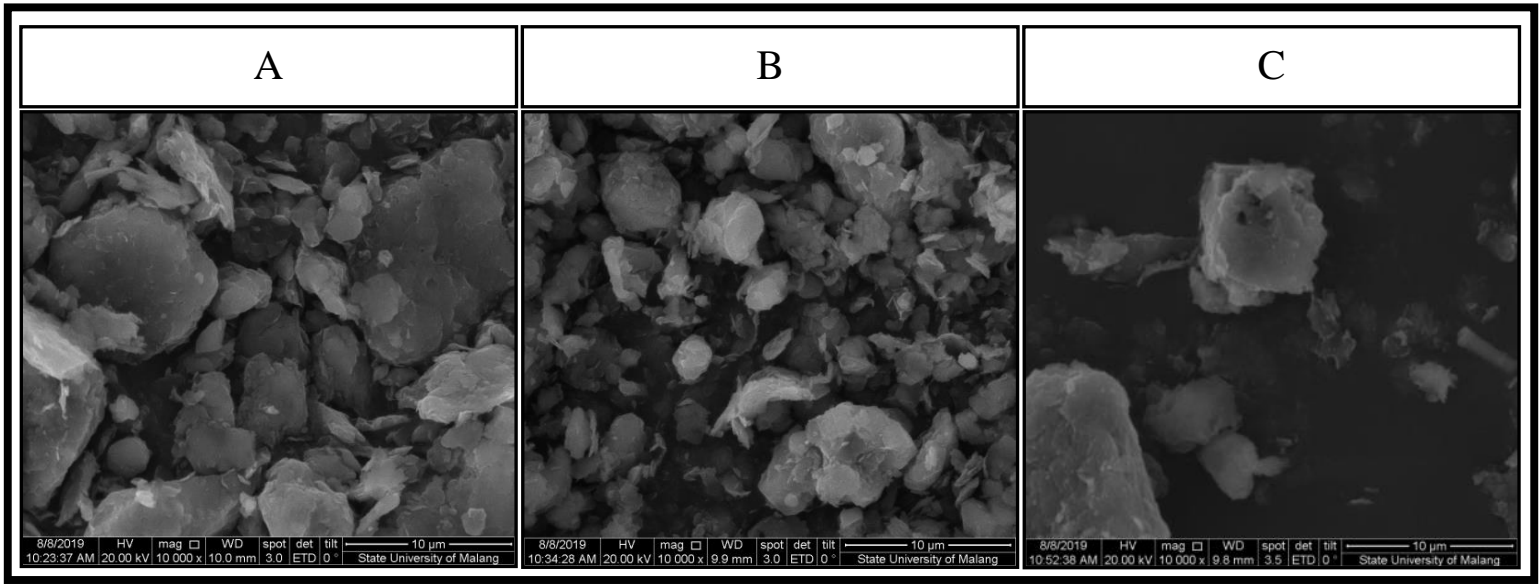

Figure 6. SEM Test with 10,000 x Magnification of (A) Waru 1, (B) Waru 2 and (C) Waru 3

With the porosity of the three samples, the synthesis process is only smoothing and normal sifting with a temperature treatment only to remove the water content of a material that is a temperature of $100^{\circ} \mathrm{C}$, which is a possible cause of frequent landslides due to the density of a sand is still lacking, causing easy the ground moves because there are still many cavities in the soil.

\section{CONCLUSION}

The location of cracks has the potential for landslides, the more cracks in the subsurface, the more potential for landslides. Normal fault and sliding fault in the subsurface cause landslides, because this fault is a plane slip and block movement. The slope of the land surface causes landslides, the higher the surface slope, the more potential for landslides.

The results of X-Ray Fluorescence (XRF) analysis showed that the highest content of Waru 1 was Si 58.3, Waru 2 was Ca 71.37\%, and in Waru 3 Si 43.3\%. The results of X-Ray Diffraction (XRD) analysis showed a qualitative mineral content in Waru 1 and Waru 2 in the form of $\mathrm{SiO} 2$ compounds (> 88\%), Waru 3 in the form of $\mathrm{CaCo} 3$ compounds by $75.2 \%$. The results of Scanning Electron Microscopy (SEM) at 10,000x magnification in Waru 1 are almost homogeneous samples in the form of slabs which identify the uneven grain size and with a little porosity indicating the sample is partially amorphous in structure, in Waru 2 shows an inhomogeneous sample ( $\mathrm{CaCO} 3$ distribution and $\mathrm{SiO} 2$ is uneven) with a fairly high porosity distribution and not equally, whereas in Waru 3 the samples show that there is an almost cube crystal shape with high porosity so that it causes frequent landslides because the density of a sand is still lacking so that it is easy to displace the soil because there are still many cavities in the soil with a size of the three samples that is $10 \mu \mathrm{m}$ or $10,000 \mathrm{~nm}$.

\section{ACKNOWLEDGMENT}

thanks to the ministry of research, technology, and higher education for providing funding, support, and guidance for this research. 


\section{REFERENCES}

1 Peraturan Daerah Kabupaten Pamekasan nomor 16 Tahun 2012 tentang Rencana Tata Ruang Wilayah Kabupaten Pamekasan 2012-2032

2 Ngadenin, K. S. W., \& Subiantoro, L. 2014. Studi awal geologi di wilayah kabupaten pamekasan untuk mendukung pemilihan calon tapak instalasi desalinasi nuklir Eksplorium, 35(1), 29-42

3 Maharani, I., Arzaqi, T., Faresi, Z., Septian, R., \& Sugiyanto, D. 2018. Identify Landslide Areas Using Resistivity Methods Wenner- Schlumberger Configuration in Meunasah Krueng Kala Area, Aceh Besar. J. Aceh Phys. Soc,7(3), 139-143

4 Sass, O., Bell, R., \& Glade, T. 2008. Comparison of GPR, 2D-resistivity and traditional techniques for the subsurface exploration of the Öschingen landslide, Swabian Alb (Germany), Geomorphology, 93(1-2), 89-103

5 Perrone, A., Lapenna, V., \& Piscitelli, S. 2014. Electrical resistivity tomography technique for landslide investigation: A review. Earth-Science Rev., 135, 65-82

6 Ariyanto, S. V., Zuhri, M. D., Kasanova, R., Darmawan, I., \& Hari, N. H. 2019. Investigation of landslide zones with geoelectric methods for disaster mitigation in Pamekasan. IOP Conference Series: Earth and Environmental Science, 243(1), 1-9

7 Souisa, M., Hendrajaya, L., \& Handayani, G. 2018. Analisis Bidang Longsor Menggunakan Pendekatan Terpadu Geolistrik , Geoteknik Dan Geokomputer di Negeri Lima Ambon. Indones. J. Appl. Phys., 8(1), 13-25

8 Dalimunthe, Y. K. 2018. Interpretation subsurface area with geoelectricity method to obtain fault field: Case study in Karang Indah village, South OKU Regency, South Sumatera. 2018 Advances in Science and Engineering Technology International Conferences (ASET), 1-4

9 Braun, J., Simon-Labric, T., Murray, K. E., \& Reiners, P. W. 2014. Topographic relief driven by variations in surface rock density, Nat. Geosci., 7(7), 534-540

10 Vanacker, V., Vanderschaeghe, M., Govers, G., Willems, E., Poesen, J., Deckers, J., \& De Bievre, B. 2003. Linking hydrological, infinite slope stability and land-use change models through GIS for assessing the impact of deforestation on slope stability in high Andean watersheds. Geomorphology, 52(3-4), 299-315

11 Hazreek, M., \& Zainal, B. 2012. Integral Analysis of Geoelectrical ( Resistivity ) and Geotechnical ( Spt ) Data in Slope Stability Assessment. Acad. J. Sci, 1(2), 305-316

12 Ramdhani, E. P., Wahyuni, T., Ni'mah, Y. L., Suprapto, S., \& Prasetyoko, D. 2018. Extraction of alumina from red mud for synthesis of mesoporous alumina by adding $\mathrm{CTABr}$ as mesoporous directing agent. Indonesian Journal of Chemistry, 18(2), 337-343

13 Rosalia, R., Asmi, D., \& Suka, E. G. 2017. Preparasi dan Karakterisasi Keramik Silika $\left(\mathrm{SiO}_{2}\right)$ Sekam Padi dengan Suhu Kasinasi $800^{\circ} \mathrm{C}-1000^{\circ} \mathrm{C}$. Jurnal Teori dan Aplikasi Fisika, 4(1), 101-106 